\title{
Pengaruh Spirulina terhadap Kadar $\beta$ hCG Tikus Bunting yang Diinduksi Interleukin-6 (Studi Bahan Biologis Tersimpan)
}

\author{
Harry K Gondo ${ }^{1 *}$, Elizabeth Haryanti ${ }^{2}$ \\ SMF/Bagian Obstetri dan Ginekologi ${ }^{1}$ \\ SMF/Bagian IImu Penyakit Dalam² \\ Fakultas Kedokteran Universitas Wijaya Kusuma Surabaya \\ *e-mail: gondo.hk@gmail.com
}

\begin{abstract}
Abstrak
Preeklamsia adalah gangguan multisistem yang terjadi spesifik pada kehamilan, ditandai dengan peningkatan kadar sitokin Interleukin- 6 dan peningkatan kadar $\beta$ hCG. Spirulina termasuk dalam alga hijau-biru yang mengandung zat aktif yakni antioksidan, vitamin, mineral. mempunyai fungsi yakni antiinflamasi dan antikosidatif. Penelitian ini bertujuan untuk mengetahui pengaruh spirulina terhadap perbaikan fungsi trofoblast pada kadar hormone $\beta \mathrm{HcG}$ tikus bunting yang diinduksi oleh Interleukin-6 (studi bahan biologis tersimpan). Jenis penelitian ini eksperimental laboratorik, dengan desain posttest only control group design. Sebanyak 25 ekor tikus dengan model preeklampsia yang diinduksi Interleukin- 6 dibagi menjadi 5 kelompok: kelompok kontrol tanpa perlakuan, kelompok kontrol positif dengan induksi Interleukin-6, kelompok pemberian spirulina dosis 10, 20, dan $40 \mathrm{mg} / \mathrm{hari}$. pada akhir perlakuan diukur kadar $\beta \mathrm{hCG}$. Analisis statistik menggunakan One Way ANOVA. Hasil penelitian ini menunjukkan bahwa pemberian spirulina dengan kadar $\beta$ hCG kelompok dosis spirulina $10 \mathrm{mg} / \mathrm{hari}(85,11 \pm 25,70 \mathrm{mIU} / \mathrm{ml})$ tidak berbeda signifikan ( $p=0,353)$ dengan kelompok Dosis $20 \mathrm{mg} / \mathrm{hari}(79,65 \pm 10,65 \mathrm{mlU} / \mathrm{ml})$. Kadar $\beta$ hCG Kelompok Dosis spirulina $40 \mathrm{mg} / \mathrm{hari}$ yaitu 93,28 $\pm 17,12 \mathrm{mlU} / \mathrm{ml}$. Kadar $\beta$ hCG kelompok Dosis spirulina $10 \mathrm{mg} /$ hari dan Kelompok Dosis spirulina $40 \mathrm{mg} /$ hari tidak terdapat perbedaan signifikan $(0,730>0,05)$. Pemberian spirulina dengan dosis $10 \mathrm{mg}$ mampu menurunkan kadar $\beta$ hCG secara signifikan $(P<0,05)$ daripada dosis $20 \mathrm{mg} /$ hari dan $40 \mathrm{mg} /$ hari.
\end{abstract}

Kata Kunci: Preeklampsia, Interleukin-6, $\beta$ hCG, Spirulina

\section{Effect of Spirulina at $\mathbf{B}$ hCG Levels of Pregnant Rats Induced by Interleukin-6 (Study of Stored Biological Materials)}

\begin{abstract}
Preeclampsia is multisystem specific disorder in pregnancy. Preeclampsia characterized by increased cytokine Interleukin-6 and $\mathrm{B}$ hCG (human Chorionic Gonadotropin). Spirulina is greenblue alga contain antioxidant, vitamin, mineral. Spirulina has a potential effect as antiinflammation. The aim of this research was to know effect of spirulina to repair trophoblast at $B$ hCG level of pregnant rats with preeclampsia condition (biology material collecting). The type of this research is an experimental laboratory with post-test only control group design. Preeclampsia models induced by Interleukin-6. Twenty-five rats were grouped to five group: Control, Control Positive, Spirulina dose 10, 20, and $40 \mathrm{mg} /$ day, at the end of treatment, 6 hCG level were analyzed. Statistical analysis was used by one-way ANOVA. The results of this study
\end{abstract}


Pengaruh Spirulina terhadap Kadar $\beta$ hCG Tikus Bunting yang Diinduksi Interleukin-6...

Harry K Gondo, Elizabeth Haryanti

showed that $B$ hCG level of group spirulina dose $10 \mathrm{mg} /$ day $(85.11 \pm 25.70 \mathrm{mlU} / \mathrm{ml})$ did not significantly different $(p=0.353)$, with group Dose $20 \mathrm{mg} /$ day $(79.65 \pm 10.65 \mathrm{~m} / \mathrm{U} / \mathrm{ml})$. Level of $B$ hCG in Spirulina group dose $40 \mathrm{mg} /$ day were $93.28 \pm 17.12 \mathrm{mIJ} / \mathrm{ml}$. The spirulina groups dose $10 \mathrm{mg} /$ day and dose $40 \mathrm{mg} /$ day did not show significantly different level of $B$ hCG $(0.730>0.05)$. Administration of spirulina at a dose of $10 \mathrm{mg}$ was able to significantly reduce levels of $B$ hCG (P $<0.05$ ) than at doses of $20 \mathrm{mg} /$ day and $40 \mathrm{mg} /$ day.

Keywords: Preeclampsia, Interleukin-6, 6 hCG, Spirulina

\section{PENDAHULUAN}

Patologi kehamilan adalah penyulit atau gangguan atau komplikasi yang menyertai ibu saat hamil (Sujiyatini, 2009). Lebih dari 63.000 ibu meninggal setiap tahunnya didunia karena preeklampsia. Kematian ibu yang terjadi di seluruh dunia diperkirakan mencapai angka 287.000 pada tahun 2010 dengan kejadian terbanyak di negara berpenghasilan rendah atau menengah. Proporsi kematian tersebut juga terkait dengan gangguan hipertensi terutama pada kehamilan (Say et al, 2014). Preeklamsia dan eklamsia merupakan ancaman di negara maju atau berkembang yang berkontribusi terhadapa morbiditas dan mortalitas maternal dan perinatal (Chuppana et al, 2018). Preeklamsia adalah komplikasi pada kehamilan yang ditandai dengan tekanan darah sistolik dan diastolik di atas 140 dan $90 \mathrm{mmHg}$ setelah kehamilan minggu ke 20, disertai dengan proteinuria lebih dari 300mg/L dalam 24 jam (Mihu et al, 2015). Sampai saat ini preeklampsia belum diketahui dengan jelas patofisiologinya. Sebagai penanda terjadinya preeklampsia. Pada kasus preeklampsia terjadi peningkatan kadar $\beta$ hCG serum (Priyatini, 2004).

Human chorionic gonadotropin (hCG) adalah hormon glikoprotein terdiri dari dua subunit $\alpha$ dan $\beta$ yang berikatan non kovalen. Hormon $\beta$ hCG diproduksi oleh sel trophoblast sinsitiotrofoblas plasenta. Puncak dari kadar $\beta$ hCG adalah minggu ke 8 - 10 kehamilan dan kadar paling rendah pada minggu $18-20$ kehamilan (Choudhury, 2012). Fungsi $\beta$ hCG pada kehamilan adalah sebagai penghasil progresteron, implantasi dan sebagai regulasi sistem kekebalan (Norris et al, 2011).

Spirulina platensis adalah salah satu varian Spirulina sp. yang telah dimanfaatkan karena kandungan nutrisinya yang lengkap (Oliveira et al 2008). Spirulina platensis memiliki beberapa pigmen alami. Fikosianin adalah salah satu dari tiga pigmen (klorofil dan karotenoid) yang bermanfaat sebagai antioksidan (Arylza, 2005). Antioksidan adalah substansi yang menetralkan aksi radikal bebas. Substansi ini membantu tubuh untuk menghalangi 
radikal bebas dengan mendonorkan elektron. Antiosidan fikosianin pada spirulina merupakan antioksidan terlarut yang sangat kuat yang berpotensi sebagai antivirus dan antikanker juga diuji dalam kemampuannya dalam kapasitas imunomodulator (Asghari et al, 2016). Potensi spirulina sebagai antioksidan ini diharapkan dapat memperbaiki respon inflamasi yang mungkin terjadi pada kondisi preeklamsia.

Berdasarkan permasalahan tersebut tentang kegunaan spirulina dalam bidang penelitian maka penelitian ini bertujuan untuk mengetahui pengaruh spirulina terhadap perbaikan fungsi trofoblast pada kadar $\beta$ hCG tikus bunting preeklampsia (studi bahan biologis tersimpan). Spirulina memiliki zat sebagai antiinflamasi dan antioksidant diharapkan akan memperbaiki atau menghambat kerusakan sel trophoblast (apoptosis), pada penelitian ini yang di ukur adalah hormon $\beta$ hCG, sebagai salah satu hormon yang dihasilkan oleh sel Trofobast.

\section{BAHAN DAN METODE}

Rancangan yang digunakan pada penelitian ini adalah menggunakan rancangan Post Test Only Control Group Design. Desain ini melibatkan subjek secara random pada salah satu dari lima kelompok. Sebanyak 25 ekot tikus betina bunting dibagi menjadi tiga kelompok diberi perlakuan dan dua kelompok kontrol; satu dari kelompok perlakuan dan satu dari kelompok kontrol diberi perlakuan eksperimental (Emzir, 2007)

P0 = Kelompok perlakuan Interleukin-6 (IL6) dengan dosis $5 \mathrm{ng} / 100 \mathrm{gram} /$ hari (i.v)

P1 = Kelompok perlakuan IL-6, $5 \mathrm{ng} / 100 \mathrm{gram} / \mathrm{hr}$ dengan Spirulina dosis $10 \mathrm{mg} /$ hari per oral

P2 = Kelompok perlakuan IL-6, 5ng/100gram/hr dengan Spirulina dosis $20 \mathrm{mg} /$ hari per oral P3 = Kelompok perlakuan IL-6, $5 \mathrm{ng} / 100 \mathrm{gram} / \mathrm{hr}$ dengan Spirulina dosis $40 \mathrm{mg} /$ hari per oral

Kemudian, diukur kadar $\beta$ hCG masing masing masing kelompok perlakuan dan di uji dengan analisis statistik menggunakan tes One Way Anova.

\section{Metode induksi preeklamsia}

Tikus betina dengan umur 2 sampai 3 bulan di pisahkan dengan tikus jantan selama dua minggu untuk menyeragamkan usia kebuntingan. Selanjutnya tikus betina dikawinkan dengan tikus jantan, lalu dilakukan pengamatan terbentuknya vaginal plug pada tikus betina setelah dikawinkan. Tikus yang telah dinyatakan bunting akan di bagi menjadi 5 kelompok dengan setiap kelompok berisi lima tikus. Tikus diadaptasi selama 7 hari, selanjutnya 
Pengaruh Spirulina terhadap Kadar $\beta$ hCG Tikus Bunting yang Diinduksi Interleukin-6...

Harry $K$ Gondo, Elizabeth Haryanti

tikus pada kelompok P0, P1, P2, dan P3 diinjeksikan IL-6 menggunakan wing needle pada vena ekor dengan dosis $5 \mathrm{ng} / 100$ gram BB selama tiga hari sebagai model tikus preeklampsia. Spirulina pada masingmasing kelompok diberikan yaitu P1 dosis sebesar 10mg/ BB/ hari; P2 dengan dosis 20 $\mathrm{mg} / \mathrm{BB} /$ hari; dan $\mathrm{P} 3$ dengan dosis $40 \mathrm{mg} /$ BB/ hari. Setelah perlakuan hewan coba, kelompok kontrol dan kelompok perlakuan diberikan dengan ketamin 0,5 $\mathrm{mg}$ peroral untuk diterminasi dan diukur kadar $\beta$ hCG.

HASIL

Hasil analisis hormon $\beta$ hCG akibat pemberian interleukin-6 dapat diamati pada Gambar 1. di bawah ini.

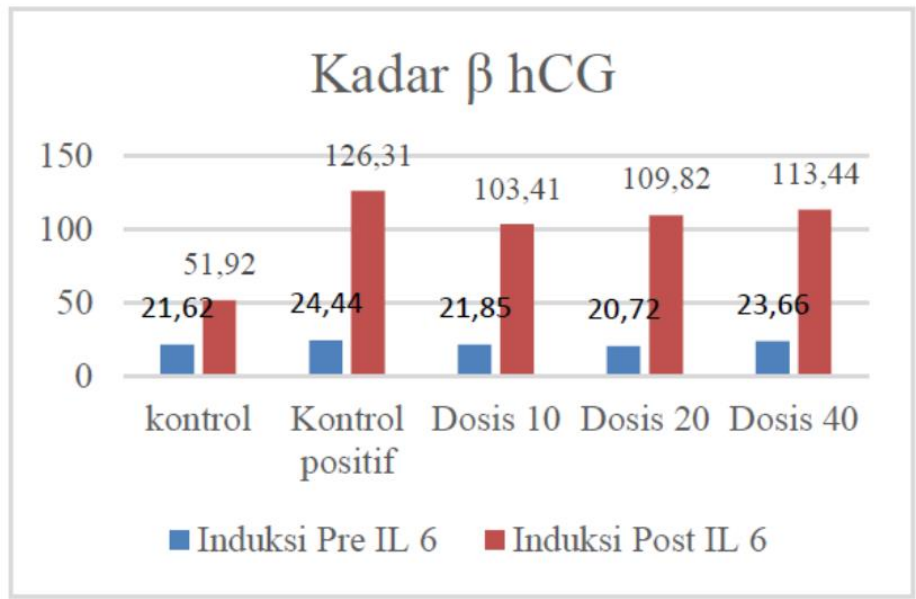

Gambar 1. Perbedaan BHcG Sebelum dan sesudah diinduksi Interleukin-6

Berdasarkan Gambar 1 menunjukan bahwa induksi Interleukin-6 dengan dosis 5 $\mathrm{mg} / \mathrm{hr}$ selama 3 hari mampu meningkatkan kadar $\beta$ hCG dari kelompok kontrol positif sebelum diinduksi Interleukin-6 sebesar $24,44 \pm 6,49 \mathrm{mlU} / \mathrm{ml}$ menjadi $126,31 \pm$ 47,09 $\mathrm{mlU} / \mathrm{ml}$ setelah diinduksi Interleukin6. Pada kelompok Dosis spirulina $10 \mathrm{mg} / \mathrm{hr}$ sebelum diinduksi Interleukin-6 sebesar $21,85 \pm 3,23 \mathrm{mlU} / \mathrm{ml}$ menjadi 103,41 \pm 28,30 $\mathrm{mlU} / \mathrm{ml}$ setelah diinduksi Interleukin6. Pada kelompok Dosis spirulina $20 \mathrm{mg} / \mathrm{hr}$ sebelum diinduksi Interleukin-6 sebesar $20,72 \pm 4,98 \mathrm{mlU} / \mathrm{ml}$ menjadi $109.82 \pm$ $20.87 \mathrm{mIU} / \mathrm{ml}$ setelah diinduksi Interleukin6. Pada kelompok Dosis spirulina $40 \mathrm{mg} / \mathrm{hr}$ sebelum diinduksi Interleukin- 6 sebesar $23,66 \pm 4,98 \mathrm{mlU} / \mathrm{ml}$ menjadi $113,44 \pm$ 20,18 $\mathrm{mIU} / \mathrm{ml}$ setelah diinduksi Interleukin6. Perbedaan kadar $\beta$ hCG pada masingmasing kelompok sebelum dan sesudah induksi interleukin-6 dapat dilihat pada Tabel 1. 
ISSN 1978-2071 (Print); ISSN 2580-5967 (Online) Jurnal IImiah Kedokteran Wijaya Kusuma 10(1): 84-91, Maret 2021

Tabel 1. Kadar $\beta$ hCG sebelum dan sesudah induksi interleukin-6

\begin{tabular}{ccc}
\hline $\begin{array}{c}\text { Kelompok } \\
\text { Perlakuan }\end{array}$ & \multicolumn{2}{c}{$\bar{X} \pm \mathrm{SD}$} \\
\cline { 2 - 3 } & $\begin{array}{c}\text { Sebelum induksi } \\
\text { Interleukin-6 }\end{array}$ & $\begin{array}{c}\text { Sesudah induksi } \\
\text { Interleukin-6 }\end{array}$ \\
\hline K & $21,61 \pm 2,71 \mathrm{mIU} / \mathrm{ml}$ & $51,92 \pm 7,01 \mathrm{mIU} / \mathrm{ml}$ \\
\hline P0 & $24,45 \pm 6,49 \mathrm{mIU} / \mathrm{ml}$ & $\begin{array}{c}126,31 \pm 47,09 \\
\mathrm{mIU} / \mathrm{ml}\end{array}$ \\
\hline P1 & $21,85 \pm 3,23 \mathrm{mIU} / \mathrm{ml}$ & $\begin{array}{c}103,41 \pm 28,30 \\
\mathrm{mIU} / \mathrm{ml}\end{array}$ \\
\hline P2 & $20,72 \pm 4,98 \mathrm{mIU} / \mathrm{ml}$ & $\begin{array}{c}109.82 \pm 20.87 \\
\mathrm{mIU} / \mathrm{ml}\end{array}$ \\
\hline P3 & $23,66 \pm 4,98 \mathrm{mIU} / \mathrm{ml}$ & $\begin{array}{c}113,44 \pm 20,18 \\
\mathrm{mIU} / \mathrm{ml}\end{array}$ \\
\hline
\end{tabular}

Kadar hormon $\beta$ hCG setelah dan sebelum pemberian Spirulina ditampilkan pada Gambar 2.

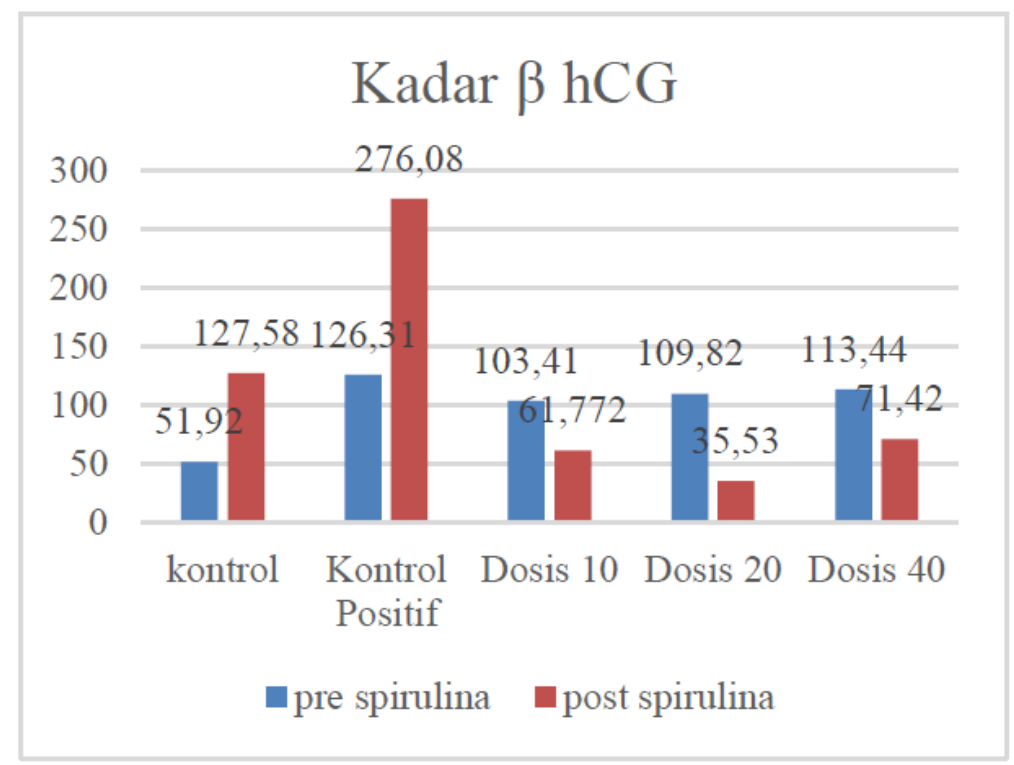

Gambar 2. Perbedaan BHcG Sebelum diinduksi dan sesudah di induksi Interleukin-6 dengan pemberian spirulina.

Pemberian spirulina dengan dosis

$10 \mathrm{mg} / \mathrm{hr}$, dosis $20 \mathrm{mg} / \mathrm{hr}$, dan dosis 40

$\mathrm{mg} / \mathrm{hr}$ selama 5 hari mampu menurunkan

kadar $\beta$ hCG. Pada kelompok Dosis spirulina

$10 \mathrm{mg} / \mathrm{hr}$ sebelum diberi spirulina sebesar

$103,41 \pm 28,30 \mathrm{mIU} / \mathrm{ml}$ menjadi $61,772 \pm$

$18,44 \mathrm{mIU} / \mathrm{ml}$ setelah diberi spirulina. Pada

kelompok Dosis spirulina $20 \mathrm{mg} / \mathrm{hr}$ sebelum

diberi spirulina sebesar $109.82 \pm 20.87$
$\mathrm{mlU} / \mathrm{ml}$ menjadi $35,53 \pm 8,61 \mathrm{mlU} / \mathrm{ml}$ setelah diberi spirulina. Pada kelompok Dosis spirulina $40 \mathrm{mg} / \mathrm{hr}$ sebelum diberi spirulina sebesar 113,44 $\pm 20,18 \mathrm{mlU} / \mathrm{ml}$ menjadi $71,42 \pm 15,99 \mathrm{mlU} / \mathrm{ml}$ setelah diberi spirulina. Perbedaan kadar $\beta$ hCG pada masing-masing kelompok sebelum dan sesudah pemberian spirulina berbagai dosis dapat dilihat pada Tabel 2 . 
Pengaruh Spirulina terhadap Kadar $\beta$ hCG Tikus Bunting yang Diinduksi Interleukin-6...

Harry $K$ Gondo, Elizabeth Haryanti

Tabel 2. Kadar $\beta$ hCG sebelum dan sesudah pemberian spirulina

\begin{tabular}{ccc}
\hline Kelompok & \multicolumn{2}{c}{$\bar{X} \pm$ SD } \\
\cline { 2 - 3 } Perlakuan & $\begin{array}{c}\text { Sebelum pemberian } \\
\text { Spirulina }\end{array}$ & $\begin{array}{c}\text { Sesudah pemberian } \\
\text { spirulina }\end{array}$ \\
\hline K & $51,92 \pm 7,01 \mathrm{mIU} / \mathrm{ml}$ & $127,58 \pm 21,1 \mathrm{mIU} / \mathrm{ml}$ \\
\hline P0 & $126,31 \pm 47,09 \mathrm{mIU} / \mathrm{ml}$ & $276,08 \pm 143,7 \mathrm{mIU} / \mathrm{ml}$ \\
\hline P1 & $103,41 \pm 28,30 \mathrm{mIU} / \mathrm{ml}$ & $61,772 \pm 18,44 \mathrm{mIU} / \mathrm{ml}$ \\
\hline P2 & $109.82 \pm 20.87 \mathrm{mIU} / \mathrm{ml}$ & $35,53 \pm 8,61 \mathrm{mIU} / \mathrm{ml}$ \\
\hline P3 & $113,44 \pm 20,18 \mathrm{mIU} / \mathrm{ml}$ & $71,42 \pm 15,99 \mathrm{mIU} / \mathrm{ml}$ \\
\hline
\end{tabular}

\section{PEMBAHASAN}

Pengaruh Interleukin-6 pada kadar Hcg tikus bunting putih

Penelitian ini menggunakan 25 ekor tikus putih bunting dilakukan dengan cara diinduksi Interleukin-6 dengan dosis 5mg selama 3 hari untuk menjadikan model preeklampsia, analisa $\beta$ hCG dilakukan untuk mengetahui peningkatan kadar hormon hCG. Menurut penelitian (Gadonski, 2006) penambahan Interleukin6 mampu meningkatkan tekanan darah dan meningkatkan sitokin proinflamasi TNF alfa dan GFR. Menurut penelitian Gokdeniz (2000) pada 3 wanita yang preeklaampsia didapatkan peningkatan $\beta$ hCG daripada wanita yang tidak preeklampsia. Hasil penelitian tersebut sesuai dengan penelitian ini bahwa pemberian Interleukin6 dengan dosis 5 mg selama 3 hari mampu meningkatkan kadar kadar $\beta$ hCG dari 22,66 $\pm 42,7 \mathrm{mlU} / \mathrm{ml}$ ke $113,24 \pm 29,11 \mathrm{mlU} / \mathrm{ml}$ $(0,001<0,005)$.

Pengaruh spirulina terhadap kadar $\beta$ hCG pada tikus putih bunting yang diinduksi Interleukin-6
Spirulina adalah mikroalga yang memiliki cyanobacterium mikroskopik berfilamen, mengandung bahan Cfikosianin yang merupakan zat dengan aktivitas kemopreventif kanker yang poten (Ravi et al, 2010). Zat ini mampu menginduksi apoptosis dengan cara memfragmentasi DNA dan kondensasi nukleus. Penelitian yang lain menyebutkan bahwa C-fikosianin dari spirulina memiliki kemampuan untuk menurunkan regulasi protein anti apoptosis dan meningkatkan regulasi protein proapoptosis (Belay, 2002), juga mempunyai fungsi sebagai antioksidan yang mampu menghambat perkembangan imunomodulator (Arylza, 2005). Antiosidan fikosianin pada spirulina merupakan antioksidan terlarut yang sangat kuat (Asghari et al, 2016)

Hasil penelitian ini menunjukkan bahwa pemberian spirulina dengan kadar $\beta$ hCG kelompok Dosis spirulina $10 \mathrm{mg} / \mathrm{hr}$ tidak berbeda signifikan dengan kelompok dosis $20 \mathrm{mg} / \mathrm{hr}(0,537>0,05)$, kadar $\beta$ hCG dosis spirulina $10 \mathrm{mg} / \mathrm{hr}$ lebih tinggi yakni $61,772 \pm 18,44 \mathrm{mlU} / \mathrm{ml}$ dari Dosis spirulina 
$20 \mathrm{mg} / \mathrm{hr}$ sebesar $35,53 \pm 8,61 \mathrm{mlU} / \mathrm{ml}$. Pada Kadar $\beta$ hCG kelompok Dosis spirulina 10 mg/hr dan Kelompok Dosis spirulina 40 $\mathrm{mg} / \mathrm{hr}$ tidak terdapat perbedaan signifikan $(0,820>0,05)$, kadar $\beta$ hCG Kelompok Dosis spirulina $40 \mathrm{mg} / \mathrm{hr}$ lebih tinggi yakni 61,772 $\pm 18,44 \mathrm{mIU} / \mathrm{ml}$ sedangkan Kelompok Dosis spirulina $10 \mathrm{mg} / \mathrm{hr}$ sebesar 71,42 $\pm 15,99$ $\mathrm{mlU} / \mathrm{ml}$.

\section{Dosis Efektif Spirulina}

Dalam penelitian ini pemberian spirulina diberikan dalam 3 dosis bertingkat yaitu $10 \mathrm{mg} / \mathrm{hr}$, $20 \mathrm{mg} / \mathrm{hr}$, dan $40 \mathrm{mg} / \mathrm{hr}$. dari ketiga dosis spirulina yang diberikan tersebut didapatkan hasil dosis efektif yaitu 10 mg karena mampu menurunkan kadar $\beta$ hCG secara signifikan daripada dosis $20 \mathrm{mg}$ dan $40 \mathrm{mg}$ dengan nilai signifikan (sig. < 0,005). Sotler et al (2019) menyatakan bahwa penambahan antioksidan dalam jumlah berlebih fungsinya tidak lagi menjadi antioksidan, melainkan menjadi prooksidan, sehingga Spirulina yang berfungsi sebagai antioksidan menjadi radikal bebas yang dapat merusak trofoblas dan uterus. Dalam penelitian Spirulina dosis $20 \mathrm{mg}$ dan $40 \mathrm{mg}$ menjadi prooksidan karena dosisnya belebih dapat menurunkan kadar $\beta$ hCG tetapi tidak signifikan.

\section{KESIMPULAN}

Pemberian Interleukin-6 dengan dosis $5 \mathrm{mg}$ selama 3 hari pada tikus bunting mampu meningkatkan kadar $\beta$ hCG secara signifikan $(P<0,05)$ yakni dari $22,66 \pm 42,7$ $\mathrm{mlU} / \mathrm{ml}$ ke 113,24 $\pm 29,11 \mathrm{mlU} / \mathrm{ml}$. Pemberian Spirulina selama 5 hari mampu menurunkan kadar $\beta$ hCG secara signifikan yakni dari 108,89 $\pm 23,11 \mathrm{mlU} / \mathrm{ml}$ ke 56,24 \pm $14,34 \mathrm{mIU} / \mathrm{ml}$. Dosis efektif Spirulina adalah 10 mg karena Kadar $\beta$ hCG lebih rendah dari kelompok Dosis $10 \mathrm{mg}$ dan Dosis $40 \mathrm{mg}$.

\section{DAFTAR PUSTAKA}

Arylza IS, 2005. Phycocyanin dari Mikroalga Bernilai Ekonomis Tinggi sebagai Produk Industri. Oseana. 3(3): 2736.

Asghari A, et al 2016. A review on antioxidant properties of Spirulina. Journal of Applied Biotechnology Reports. 3(1): 345-351.

Belay A, 2002. The Potential Application of Spirulina (Arthrospira) as a Nutritional and Therapeutic Supplement in Health Management. The Journal of the American Nutraceutical Association Vol 5, no 2, Spring.

Choudhury 2012, Value of Serum $\beta$-hCG in Pathogenesis of Pre-Eclampsia. Journal of Clinical Gynecology and Obstetrics. 1: 71-75.

Chuppana R, Madhavi AP, Sharon PS, Priya SS, Shehnaz S, 2018. A study of maternal deaths from 
Pengaruh Spirulina terhadap Kadar $\beta$ hCG Tikus Bunting yang Diinduksi Interleukin-6...

Harry K Gondo, Elizabeth Haryanti

preeclampsia and eclampsia in a tertiary care centre. IAIM. 5(1): 610.

Emzir. 2007. Metodologi Penelitian Pendidikan Kuantitatif dan Kualitatif. Jakarta: PT Raja Grafindo Persada.

Gadonski G. 2006. Hypertension Produced by Reductions in Uterine Perfusion in the Pregnant Rat Role of Interleukin-6. Departments of Physiology and ObstetricsGynecology and Center for Excellence in CardiovascularRenal Research, University of Mississippi Medical Center, Jackson, Miss.pages 711-715.

Gökdeniz R, Ariguloglu R, Bazoglu N, Balat O, 2000. Elevated serum b-hCG levels in severe preeclampsia. Turk. J. Med. Sci. 30(2000): 43-45.

Mihu D, Razvan C, Malutan A, Mihaela C, 2015. Evaluation of maternal systemic inflammatory response in preeclampsia. Taiwanese Journal of Obstetrics and Gynecology. 54(2): 160-166.

Norris W, Nevers T, Sharma S, Kalkunte S, 2011. Review: hCG, Preeclampsia and Regulatory T cells. Placenta. 32(suppl 2): S182-S185.

Oliveira EG, Rosa GS, Moraes MA, Pinto LAA. 2008. Phycocyanin Content of Spirulina platensis dried in spouted bed and thin layer. Journal of Food Process Engineering, 31(1): 34-50.

Priyatini T, Wiknjosastro GH. 2004. Angka Kejadian Preeklampsia Berat dan Eklampsia di Rumah Sakit Umum Pusat Cipto Mangunkusumo Jakarta.

Ravi M, De SL, Azharuddin S, Paul SFD, 2010. The beneficial effects of spirulina focusing on its immunomodulatory and antioxidant properties. Nutrition and Dietary Supplements. 2: 73-83. Say L, Chou D, Gemmill A, Tuncalp O, Moller Ann-Beth et al, 2014. Global causes of maternal death: A WHO systematic analysis. The Lancet Global Health. 2(6): 323-333.

Sotler R, Poljsak B, Dahmane R, Jukic T, Jukic DP et al, 2019. Prooxidant Activities of Antioxidants and Their Impact on Health. Acta Clin Croat. 58: 726-736.

Sujiyatini, dkk. 2009. Asuhan Patologi Kebidanan. Nuha Medika, Jakarta. 